\title{
Studies on the Indo-Pacific Tridacnidae (Tridacna maxima) from the Northern Red Sea, Egypt
}

\author{
Manal S. Mekawy ${ }^{1}$, Hashem A. Madkour ${ }^{2}$ \\ ${ }^{1}$ Geology Department, Faculty of Science, Suez Canal University, Ismailia, Egypt \\ ${ }^{2}$ National Institute of Oceanography and Fisheries, Red Sea Branch, Hurghada, Egypt \\ Email:manalmekawy@hotmail.com,madkour_hashem@yahoo.com
}

Received August 5, 2012; revised September 6, 2012; accepted October 4, 2012

\begin{abstract}
In Egypt, Tridacna maxima are found in Gulf of Suez, Gulf of Aqaba and Red Sea. Tridacna maxima are very important ecological species as seafood source and as a substrate for reef-associated organisms; therefore we should protect it from extinction. Recently, these species are exposed for many factors of pollution (human activities, tourism and natural resources) that affect the distribution and abundance of it. The main objective of this research is to shed some light on the origin, stratigraphic position, systematic palaeontology and geographic distribution of Tridacna maxima. In addition to their ecologic and environmental conditions were discussed. Finally, a proposed rules for protection these species from extinction were listed. Individuals of Tridacna maxima were collected from different sites along the red Sea coast.
\end{abstract}

Keywords: Tridacna maxima; Studies; Red Sea; Egypt

\section{Introduction}

Several studies were carried out on the Egyptian Red Sea Coast. Pioneer works include; Rinkevich and Loya, Piller and Pervesler, Abdel-Salam, Jameson et al., Ziko et al., Mohammed, Dar, Madkour, Madkour and Dar, Mansour et al., Mohammed and Dar, El-Taher and Madkour and others [1-15].

Most of the previous studies were focused on the impact of the heavy metals on the marine organisms and the sediments while others focused on the study of the coral reefs. This study is the first attempt to study the status of the Egyptian giant clam Tridacna maxima that their specimens were collected from different sites in the Red Sea coast.

\section{Materials and Methods}

Tridacna maxima live near the sediment-water interface. Therefore contaminants in sediments potentially have an influence on it. The present study focuses on areas subjected to natural inputs from wadis such as Hamata area, Abu-Ghusun area and Wadi El-Gemal area; and anthropogenic activities including Quseir, Safaga, Hurghada Harbours and El-Esh area (Figure 1). Anthropogenic activities in these areas include shipment of ores such as phosphate and bauxite, coal and cement packing, renewing ship operations and shipyards, landfilling, and dredging and oil production especially in Hurghada Harbor and El-Esh area. The shells of the giant clam (Tridacna maxima) were sampled through the National Institute of Oceanography and Fisheries Red Sea Branch, Hurghada from seven sites along the Egyptian Red Sea coast using SCUBA diving (Figure 1). The temperatures of the studied localities at different depths were measured using Hydrolab Instrument, in addition some of ecologic and environmental parameters were recoded (Table 1). The giant clam shells were cleaned and the soft tissue was removed on the beach of the sampling site. The empty shells were soaked in water for 15 - 30 minutes in order to kill any clinging algae then left to dry in air. Clear and complete samples were photographed by digital camera and then displayed in Plate 1.

\section{Origin}

Giant clams (Tridacnidae) are the largest bivalve mollusks. They are attractive bivalves owing to their exceptional size and the increasing importance of these bivalves in aquaculture and scuba-diving tourism [16]. The first appearance of Tridacnidae in the Paleogene when a number of genera were to be found in Western Tethys [17]. Despite they have robust shells, their preservation as a fossils is poor. Most of Tridanidae became extinct before the Neogene, apparently due to climatic change concomitant with the breakup of the Tethy Sea [17] where the Arabian Peninsula was part of the Tethys Ocean during the Oligo-Miocene period $[18,19]$ and was situated at the junction between the western Tethyan fau- 


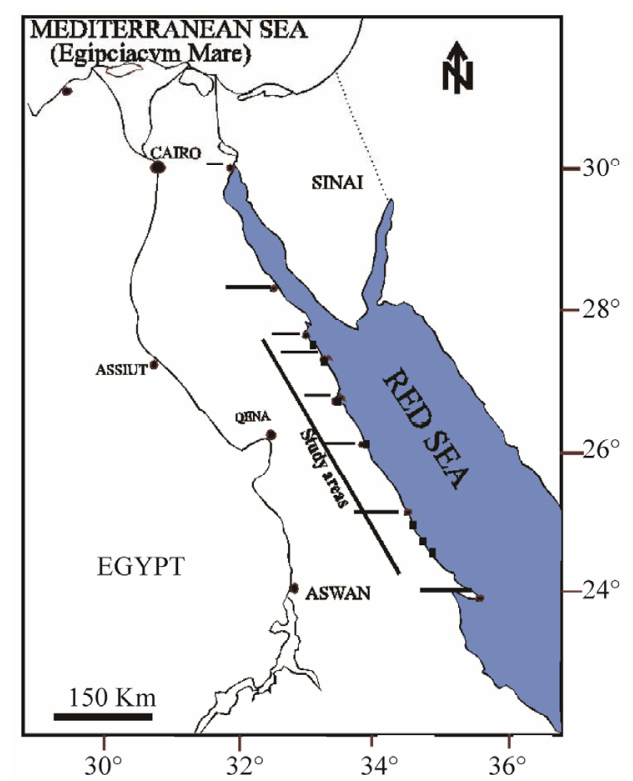

(a)

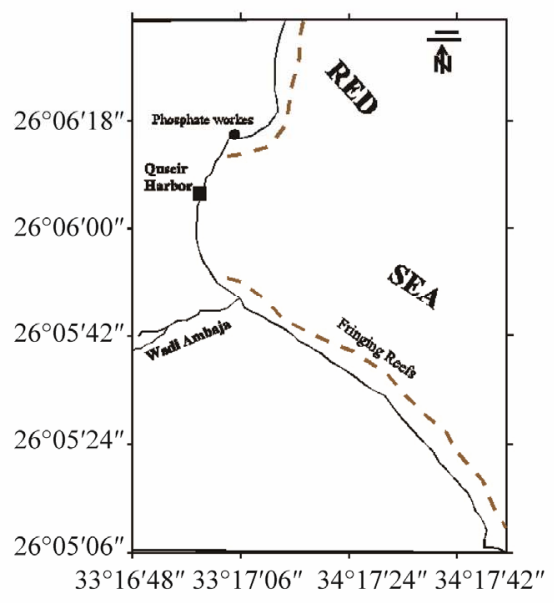

(c)

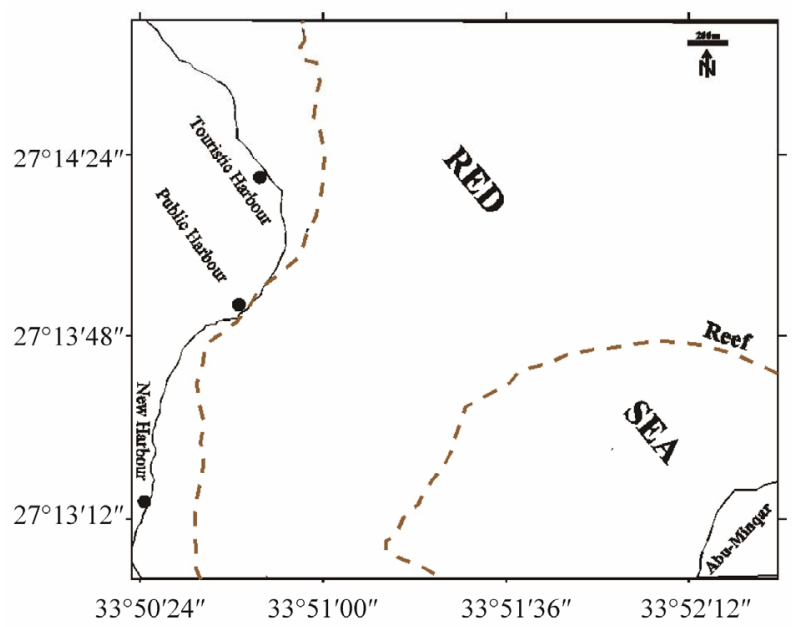

(e)

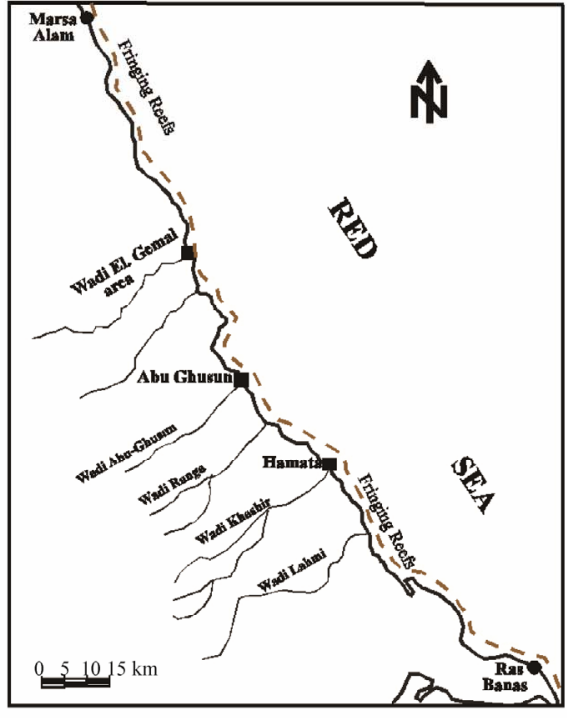

(b)

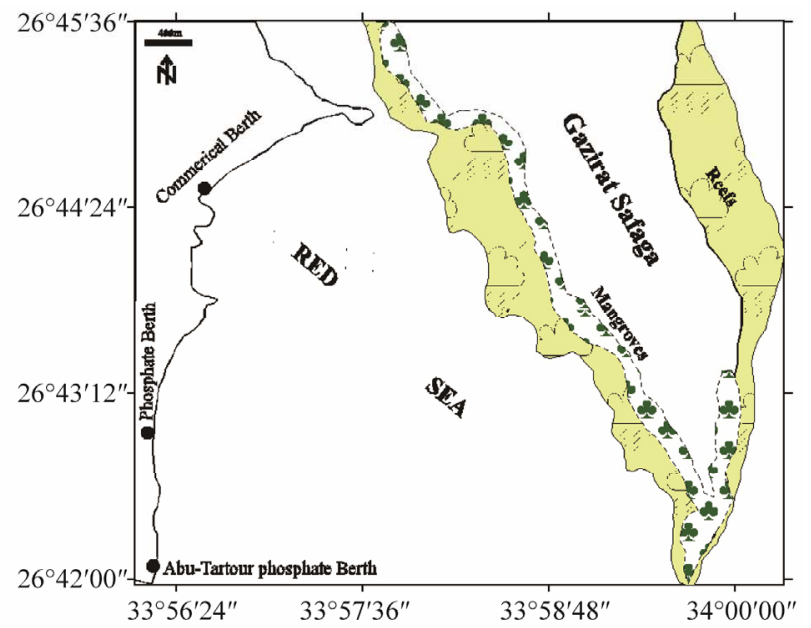

(d)

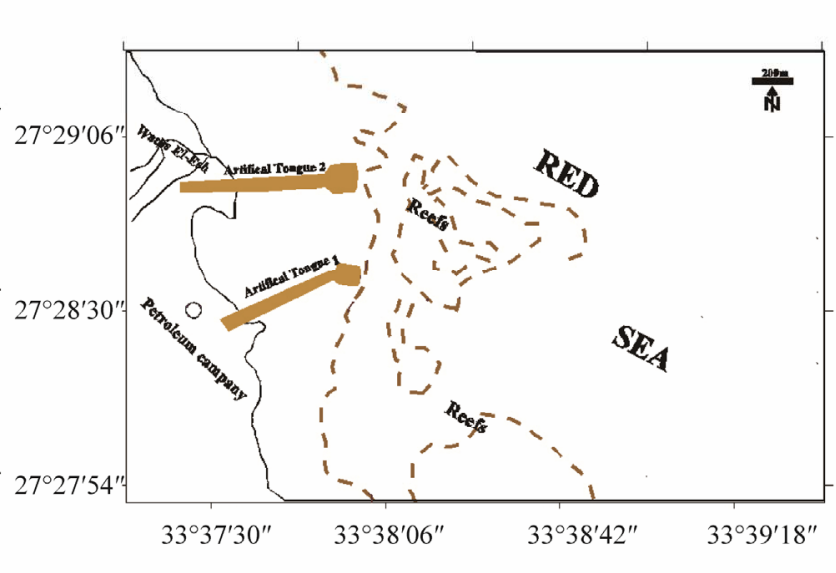

(f)

Figure 1. Location maps, general view of the Red Sea (a); Hamata, Abu-Ghusun and Wadi El-Gemal areas (b); Quseir Harbor (c); Safaga Harbor (d); Hurghada Harbor (e) and El-Esh area (f). 

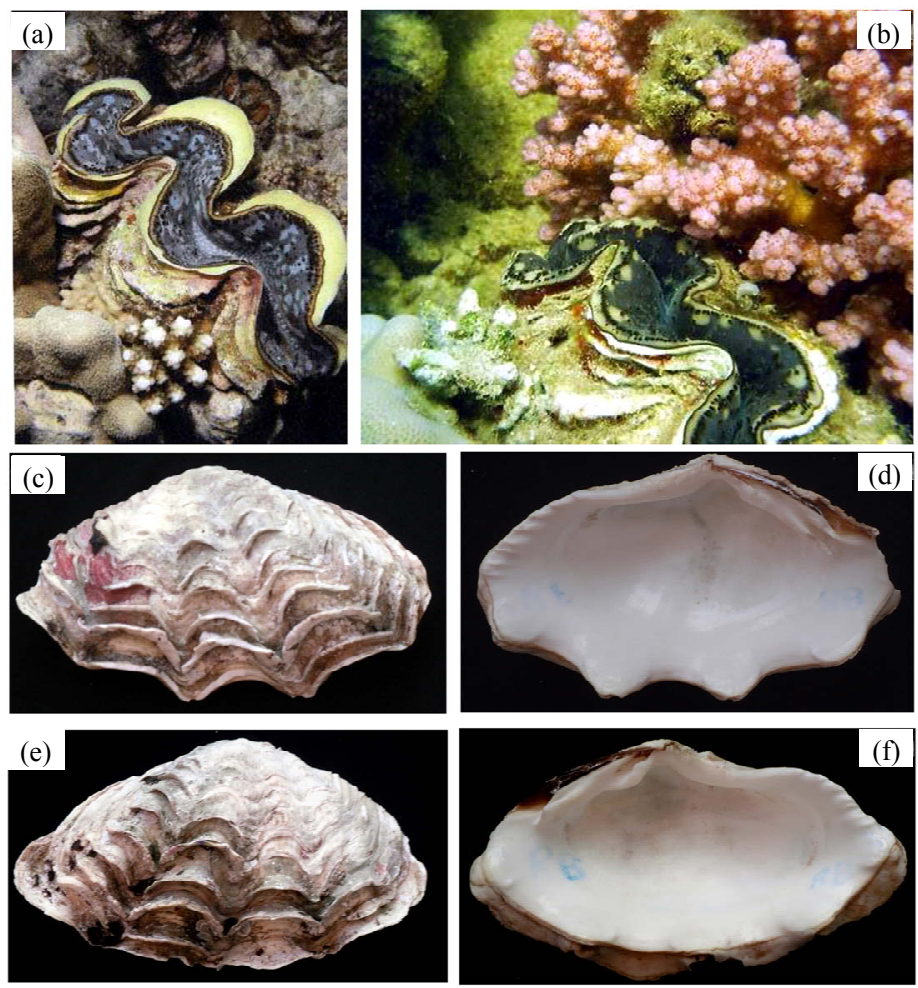

Plate 1. (a)-(b) Photographs show Tridacna maxima under water attached to coral reefs $0.4 \times$; (c)-(d) The exterior and interior views of the left valve of Tridacna maxima $0.5 \times$; (e)-(f) The exterior and interior views of the right valve of Tridacna maxima $0.5 \times$.

Table 1. Sample location, depth and measured some of ecologic and environmental parameters of the study areas.

\begin{tabular}{|c|c|c|c|c|c|c|c|c|}
\hline No. & Location & $\begin{array}{c}\text { Depth } \\
\text { (m) }\end{array}$ & Temp. ${ }^{\circ} \mathrm{C}$ & $\begin{array}{c}\text { Date } \\
\text { Month/Year }\end{array}$ & Size & Abundance & $\begin{array}{l}\text { Sedimentary } \\
\text { environment }\end{array}$ & $\begin{array}{c}\text { Marine organisms } \\
\text { associations }\end{array}$ \\
\hline 1 & El-Esh area & 5 & 22 & Winter 2002 & $\begin{array}{l}\text { (Large) } \\
\text { Giant clam }\end{array}$ & common & Biogenic sediments & $\begin{array}{l}\text { Coral reefs \& some } \\
\text { seagrassess }\end{array}$ \\
\hline 2 & Hurghada Harbor & 8 & 28 & Spring 2002 & Medium to large & rare & $\begin{array}{c}\text { Biogenic \& } \\
\text { terrestrial sediments }\end{array}$ & Coral reefs \\
\hline 3 & Safaga Harbor & 7 & 26 & Winter 2002 & Medium to large & rare & $\begin{array}{l}\text { Terrestrial } \\
\text { sediments }\end{array}$ & $\begin{array}{l}\text { Patches of coral } \\
\text { reefs }\end{array}$ \\
\hline 4 & Quseir Harbor & 3 & 25 & Summer 2002 & Medium to large & rare & $\begin{array}{l}\text { Terrestrial } \\
\text { sediments }\end{array}$ & $\begin{array}{l}\text { Patches of coral } \\
\text { reefs \& some marine } \\
\text { algae \& seagrassess }\end{array}$ \\
\hline 5 & Wadi El-Gemal & 6 & 24.6 & Summer 2006 & Medium to large & common & Terrestrial sediments & $\begin{array}{c}\text { Coral reefs \& } \\
\text { seagrassess }\end{array}$ \\
\hline 6 & Abu-Ghusun & 10 & 23.23 & Summer 2001 & $\begin{array}{c}\text { (Large) } \\
\text { Giant clam }\end{array}$ & abundant & Biogenic sediments & Coral reefs \\
\hline 7 & Hamata Reefs & 4 & 29.74 & Winter 2006 & $\begin{array}{c}\text { (Large) } \\
\text { Giant clam }\end{array}$ & abundant & Biogenic sediments & Coral reefs \\
\hline
\end{tabular}

nas and those of the Proto-Indo-Pacific. This means that Tridanidae was originally Tethyan.

In Egypt, Tridacna maxima entered into the Egyptian waters through the Red Sea which was formed about 25 million years ago when the African and Asian continental plates started to move apart. The Red Sea is a body of warm tropical water nearly $2000 \mathrm{~km}$ in length and forms the most northwestern part of the Indo-Pacific Ocean. It is a seawater inlet of the Indian Ocean that lying between Africa and Asia through the Babel Mandels strait and the Gulf of Aden.

\section{Stratigraphic Position in the Geological Column}

Tridacninae includes two extant genera, Hippopus and Tridacna, represented by three and twelve extinct and 
two and seven extant species, respectively [17]. The extant species of the genus Tridacna are T. gigas (Linnaeus, 1758), T. derasa (Röding, 1798), T. tevoroa Lucas, Ledua and Braly, 1990, T. squamosa (Lamarck, 1819), T. maxima (Röding, 1798), T. crocea Lamarck, 1819, and T. rosewateri Sirenko and Scarlato, 1991. The stratgraphic range of Tridacna species was illustrated in Table 2.

In fact, this is the first attempted to study the stratigraphic position of Tridacna maxima in Egypt. Generally, it entered into the Egyptian waters in Late Miocene (see section of origin) and continuous in the appearance until now. In the present study areas, it has been recorded abundant in the south areas especially in Hamata and Abu-Ghusun reefs (pristine and non-contaminated areas) but it is rare to frequent in the human activity sites (see Section 2).

\section{Systematic Palaeontology}

The systematic paleontology of Tridacna maxima follows [20].

Phylum: Mollusca

Class: Bivalvia Linné, 1758

Subclass: Pteriomorpha Beurlen, 1944

Superfamily: Tridacoidea Lamarck, 1819

Family: Tridacnidae Lamarck, 1819

Genus: Tridacna Beruguiere, 1797

Scientific name: Tridacna maxima (Röding, 1798)

Common name: Maxima clam or giant clam

Plate 1(a)-(f)

2000: Tridacna (Chametrachea) maxima (Röding);

Newman and Gomez, p. 5.

2008: Tridacna (Chametrachea) maxima (Röding); Harzhauser et al., p. 205.

Description: Shell is thick and heavy, small to large, elongate slender species has very low but broad radial ribs, on which are numerous large and undulating concentric scaly ridges. Most shells are particularly attractive the hinge line is about one-third of the shell; length; the byssal gape is large. The exterior is usually off white to cream; the interior is white.

Remarks: Most of the collected samples are founded in shallow reefs to about $15 \mathrm{~m}$. They are abundant in the south areas especially in Hamata reefs but rare to frequent in the human activity sites.

Distribution in Egypt: Gulf of Suez, Gulf of Aqaba and Red Sea.

Stratigraphic range: Late Miocene - Holocene.

\section{Geographic Distribution}

Tridacna, the genus of giant clams, has a very wide geographic distribution. It lives along shallow shorelines and on reefs between $30^{\circ} \mathrm{E}$ and $120^{\circ} \mathrm{W}$ (South Africa to beyond French Polynesia) and between $36^{\circ} \mathrm{N}$ and $30^{\circ} \mathrm{S}$ (Japan to Australia) [21]. Tridacna maxima is one of the most common species of giant clams world wide. Their distribution is Red Sea, Arabian and Indo-Pacific province.

\section{Ecologic and Environmental Considerations}

Tridacna are bivalve mollusks that settle and grow on rock or coral inside reef lagoons in water shallower than three meters [22]. Tridacna maxima are founded in shallow water intense sunlight is plentiful; therefore in the aquarium they should be placed where they can receive direct intense lighting have ways of attaching themselves to the coral reef, they may also burrow partially into the substrate. Although Tridanca maxima are heterotrophic filter feeders, most of the carbon required for metabolism and growth is obtained through the photosynthesis of symbiotic dinoflagellate algae (zooxanthellae) that live in the clam's mantle [23]. Tridacna maxima require calcium levels of at least $280 \mathrm{meq} / \mathrm{L}$, as well as adequate strontium, iodine and other trace elements.

\section{Field Observations}

The field observations of the studied areas were summarized in Table 1 and detailed in the following:

Table 2. Stratigraphic range of the extant Tridacna species in the geological column.

\begin{tabular}{|c|c|c|c|c|c|c|c|c|}
\hline \multirow{2}{*}{$\begin{array}{c}\text { Age } \\
\text { Species }\end{array}$} & \multirow{2}{*}{ Oligocene } & \multicolumn{2}{|c|}{ Miocene } & \multicolumn{2}{|c|}{ Pliocene } & \multicolumn{2}{|c|}{ Pleistocene } & \multirow{2}{*}{ Holocene } \\
\hline & & Early & Late & Early & Late & Early & Late & \\
\hline \multicolumn{9}{|l|}{ 1-gigas } \\
\hline \multicolumn{9}{|l|}{ 2-derasa } \\
\hline \multicolumn{9}{|l|}{ 3-maxima } \\
\hline \multicolumn{9}{|l|}{ 4-squamosa } \\
\hline \multicolumn{9}{|l|}{ 5-crocea } \\
\hline \multicolumn{9}{|l|}{ 6-levora } \\
\hline 7-rosewateri & & & & & & & & \\
\hline
\end{tabular}


El-Esh area lies about $30 \mathrm{~km}$ to the north of Hurghada $\left(27^{\circ} 27^{\prime} 93^{\prime \prime} \mathrm{N}\right.$ to $27^{\circ} 28^{\prime} 80^{\prime \prime} \mathrm{N}, 33^{\circ} 38^{\prime} 00^{\prime \prime} \mathrm{E}$ to $\left.33^{\circ} 38^{\prime} 20^{\prime \prime} \mathrm{E}\right)$. Recently, the area was subject to impacts by drilling for oil production, when more than $500 \mathrm{~m}$ long artificial sediment tongues were constructed. There are two potential sources for terrestrial materials to marine environment: anthropogenic activities and sediment input from Wadis El-Esh (Plate 2(a)-(c)).

Hurgada Harbor is located between latitudes $27^{\circ} 13^{\prime}$ $09^{\prime \prime} \mathrm{N}$ and $27^{\circ} 14^{\prime} 72^{\prime \prime} \mathrm{N}$ and longitudes $33^{\circ} 50^{\prime} 73^{\prime \prime} \mathrm{E}$ and $33^{\circ} 50^{\prime} 85^{\prime \prime} \mathrm{E}$. Generally, the northern part of the Red Sea is characterized by the existence of a wide intertidal zone ( $\sim 1000 \mathrm{~m}$ wide). The beach sediments are generally coarse sand, mixed with significant amount of biogenous fragments (Plate 2(d)). The southern area of Hurghada Harbour was exposed to some human activities by dredge works in the new harbor and disposal of garbage from the boats (Plate 2(f)). The intertidal zone is a rocky tidal flat covered with thin layer of soft deposits especially in the Public Harbour. The lagoons in front of Hurghada Harbour are covered with fine to very fine carbonate biogenous deposits. Patch reefs and fringing reefs characterize the area in front of Hurghada Harbor. The most common and widely distributed coral species in this area are Acropora sp., and Stylophora pistillata (Plate 2(e)). A long the intertidal zone, there are some patches of seagrass. Dense algal species and coralline algae are incorporated with the reefs. Gastropods, bivalves and crustaceans are observed in the area.

Safaga Harbor is the largest harbour on the Egyptian Red Sea coast. It is situated between latitudes $26^{\circ} 43^{\prime}$ $42^{\prime \prime} \mathrm{N}$ to $26^{\circ} 44^{\prime} 22^{\prime \prime} \mathrm{N}$, and longitudes $33^{\circ} 56^{\prime} 20^{\prime \prime} \mathrm{E}$ to $33^{\circ}$ $56^{\prime} 05^{\prime \prime}$. The intertidal zone in Safaga Harbour is extre-

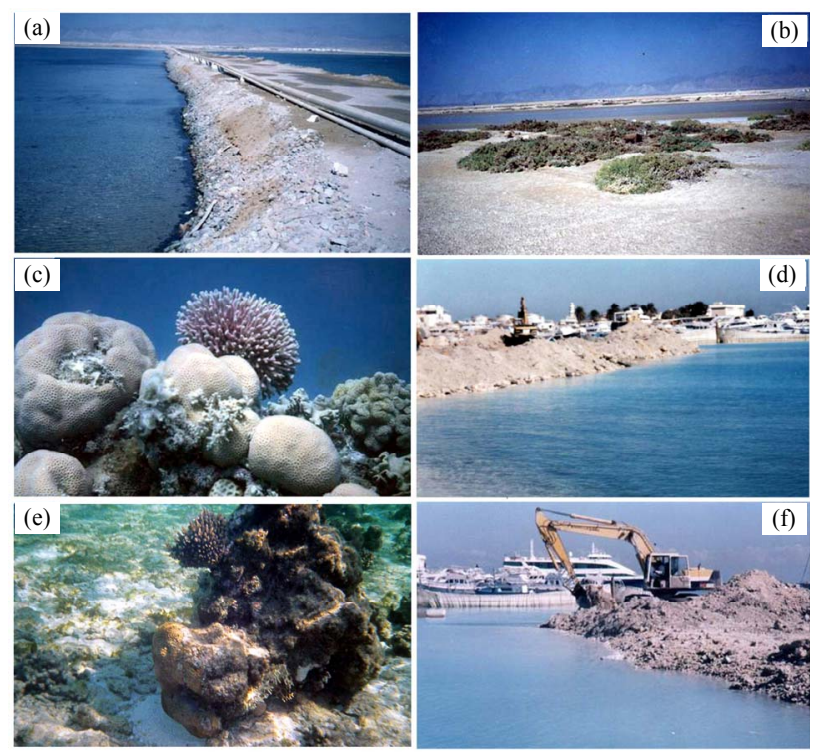

Plate 2. (a)-(c) Photographs of El-Esh area; (d)-(f) Photographs of Hurghada Harbour. mely narrow (Plate 3(a) and (b)). The coastal zone along the Red Sea at Safaga Town is a site for industrial development, and for future establishment of dense recreational resorts. It includes Safaga Harbour on which the international trade depends.

Quseir Harbor $\left(26^{\circ} 05^{\prime} 02^{\prime \prime} \mathrm{N}\right.$ to $26^{\circ} 06^{\prime} 12^{\prime \prime} \mathrm{N}, 34^{\circ} 16^{\prime}$ $58^{\prime \prime} \mathrm{E}$ to $34^{\circ} 17^{\prime} 08^{\prime \prime} \mathrm{E}$ ) is the oldest harbour at the Egyptian Red Sea coast. It is situated in a small bay at the mouth of Wadi Ambaji (Plate 3(c)). The sea bottom character includes dense seagrass meadows.

Wadi El-Gemal is one of the famous Red Sea wadis for tourism. The area is located about $50 \mathrm{~km}$ south of Marsa Alam, between latitude $24^{\circ} 39^{\prime} \mathrm{N}$ and longitude $35^{\circ} 05^{\prime} \mathrm{E}$. Wadi El-Gemal is characterized by an arid climate and dominated by hot, rainless summer and mild winter. This area is covered by seagrasses and biogenic sand (Plate 3(d)-(e)). Fringing reefs characterize the area in front of the northern part at the mouth of the wadi. The most common and widely distributed coral species in this area are Porites sp.

Abu-Ghusun Reef is located at the northern part of Hamata area. It is lying at latitudes $24^{\circ} 27^{\prime} 50^{\prime \prime} \mathrm{N}$ and longitudes $35^{\circ} 11^{\prime} 50^{\prime \prime} \mathrm{E}$. The tidal flat is characterized by its silt size sediments and rich biodiversity of seagrasses, algae, crustaceans, pelecypods, gastropods, foraminifera and some eggs belonging to marine organisms. A prominent feature characterizing the seaward edge of the tidal flat is the presence of small coral reef patches.

Hamata area represents the largest mangrove communities of the Egyptian Red Sea coast. It is lying between latitudes $24^{\circ} 21^{\prime} 31^{\prime \prime} \mathrm{N}$ to $24^{\circ} 22^{\prime} 58^{\prime \prime} \mathrm{N}$ and longitude $35^{\circ} 18^{\prime} 00^{\prime \prime} \mathrm{E}$ to $35^{\circ} 15^{\prime} 43^{\prime \prime} \mathrm{E}$. The mangrove swamp in Ha-
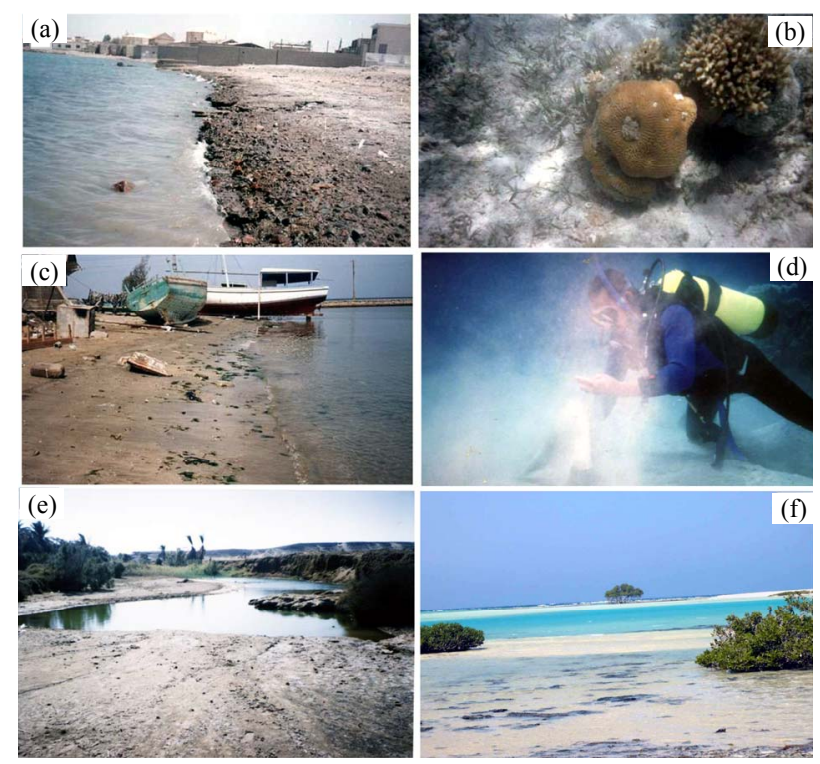

Plate 3. (a)-(b) Photographs of Safaga harbour; (c) Photographs of Quesir harbour; (d)-(e) Photographs of Wadi ElGemal; (f) Hamata Reefs. 
mata area is healthy and the height of the mangrove trees exceeds $8 \mathrm{~m}$. The mangrove swamp and surrounding areas are flatted plain with very gently sloping toward the sea (Plate 3(f)).

\section{Results and Discussion}

In these areas subjected to natural inputs from wadis (Hamata and Abu-Ghusun), it is noted that the recorded highest percentage of Tridacna maxima with large size may be a result of the two areas being far away from the human activities and water pollution or the biogenic sedimentary environment. While in Wadi El-Ge-mal, the arid and hot climate is in domination, in addition, the human activities such as the diving and tourism play an important role in distribution and abundance (common) of Tridacna maxima. In anthropogenic activities' areas (Quseir, Safaga and Hurghada Harbors), it is noted that despite the availability of the suitable water temperature and depth (Table 1), Tridacna maxima is still not abundant. The main causes of this abnormality are the high human activities and water pollution in these areas [9, 24]. While in El-Esh area, the drilling and production of oil have been affecting the distribution and abundance (common) of Tridacna maxima recently.

The present study documented the distribution of Tridacna maxima in different sedimentary environment; biogenic, Terrestrial or combination from the both (Table 1). Two major environmental factors affect the distribution of Tridacna maxima light intensity (related to the depth) and water temperature (Figures 2 and 3). The present study draws attention that Tridacna maxima in the Egyptian Red Sea Coast are endangered and may be collapse if the anthropogenic activities are continuous.

\section{Recommendations}

Tridacna maxima are very important ecological species as seafood source and as a substrate for reef-associated organisms, so we should be protect it from extinction by setting strict rules and the opposite to of them receive

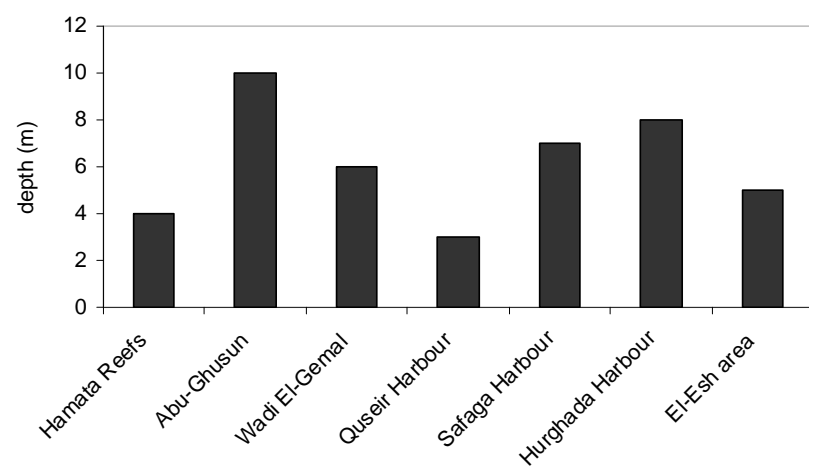

Figure 2. Distribution of Tridacna maxima according to the depth (m) of the study areas.

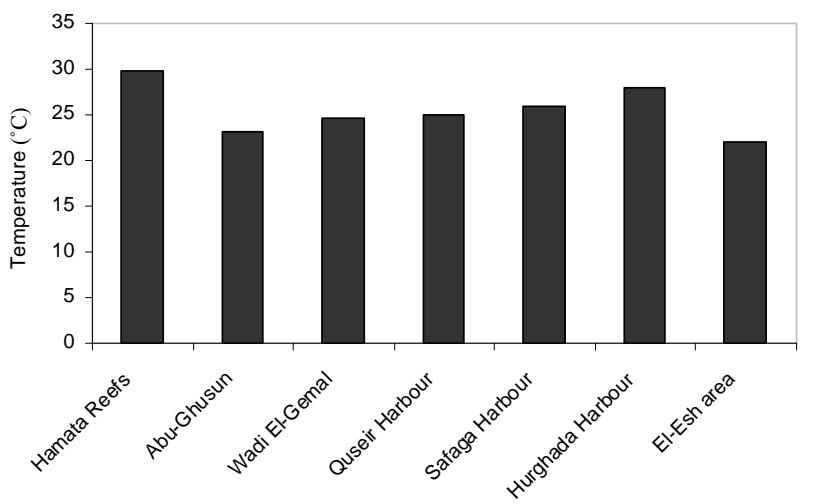

Figure 3. Distribution of Tridacna maxima according to the Temperature $\left({ }^{\circ} \mathrm{C}\right)$ of the study areas.

severe punishment. Some of the proposed rules are as the following:

1) Identify specific areas for diving, tourism and fishing and putting sings say that.

2) Prevent fishing in reproduction season.

3) Stop the drilling and production of oil in the areas of presence of Tridacna maxima and other marine organisms.

4) The areas of drilling and production of oil must be away from the coast Red Sea and the intertidal zone where presence most of marine organisms.

5) Full clean of the all contaminated areas.

\section{REFERENCES}

[1] B. Rinkevich and Y. Loya, "Harmful Effects of Chronic Oil Pollution on a Red Sea Scleractinian Coral Population," Proceedings of the 3rd International Coral Reef Symposium, Miami, 1977, pp. 585-591.

[2] B. Rinkevich and Y. Loya, "Laboratory Experiments on the Effects of Crude Oil on the Red Sea Coral Stylophra Pistillata," Marine Pollution Bulletin, Vol. 10, No. 11, 1979, pp. 328-330. doi:10.1016/0025-326X(79)90402-8

[3] W. E. Piller and P. Pervesler, "An Actuoupalaeontological Approach, the Northern Bay of Safaga, (Red Sea, Egypt)," Beitr Paläont Österr, Vol. 15, 1989, pp. 103 -147 .

[4] H. A. Abdel-Salam, "Impact of Landfilling on Coral Reef Ecosystem of South Magawish, Hurghada, Red Sea," Journal of Egypt Ger Soc Zool, Vol. 12, 1993, pp. 187197.

[5] S. C. Jameson, M. S. A. Ammar, E. Saadall, H. M. Mostafa and B. Riegl, "A Coral Damage Index and Its Application to Diving Sites in the Egyptian Red Sea," Coral Reefs, Vol. 18, No. 4, 1999, pp. 333-339. doi:10.1007/s003380050208

[6] A. Ziko, A. S. El-Sorogy, M. M. Aly and H. E. Nour, "Sea Shells as Pollution Indicators, Red Sea Coast, Egypt," Egyption Journal of Paleontol, Vol. 1, 2001, pp. 97-113.

[7] A. M. Mohammed, "Geochemical Study of Major and Trace Elements in Some Coral Species, Abu-Soma Bay, 
Red Sea, Egypt," Journal of Environmental Res Zagazig University Egypt, Vol. 4, 2002, pp. 199-213.

[8] M. A. Dar, "Heavy Metals Variability and the Bioaccumulation Mechanism in the Recent Corals, Hurghada, Red Sea, Egypt," Sedimentology of Egypt, Vol. 12, 2004, pp. 119-129.

[9] H. A. Madkour, "Geochemical and Environmental Studies of Recent Marine Sediments and Some Hard Corals of Wadi El-Gemal Area of the Red Sea, Egypt," Egyptian Journal of Aquatic Research, Vol. 31, No. 1, 2005, pp. 69-91.

[10] H. A. Madkour, "Impacts of Human Activities and Natural Inputs on Heavy Metal Contents of Many Coral Reef Environments along the Egyptian Red Sea Coast, " Arabian Journal of Geosciences, 2011. doi:10.1007/s12517-011-0482-5

[11] H. A. Madkour and M. A. Dar, "The Anthropogenic Effluents of the Human Activities on the Red Seacoast at Hurghada Harbour (Case Study)," Egyptian Journal of Aquatic Research, Vol. 33, No. 1, 2007, pp. 43-58.

[12] A. M. Mansour, A. H. Nawar and H. A. Madkour, "Metals Concentration of Recent Invertebrates along the Red sea Coast of Egypt: A Tool for Monitoring Environmental Hazards," Sedimentology of Egypt, Vol. 3, 2005, pp. 171-185.

[13] A. M. Mansour, A. H. Nawar and H. A. Madkour, "Metal Pollution in Marine Sediments of Selected Harbors and Industrial Areas along the Red Sea Coast of Egypt," Ann Naturhist Mus Wien Serie A, Vol. 113, 2011, pp. 225-244.

[14] T. A. Mohammed and M. A. Dar, "Ability of Corals to Accumulate Heavy Metals Northern Red Sea, Egypt," Environmental Earth Sciences, Vol. 59, No. 7, 2010, pp. 1525-1534. doi:10.1007/s12665-009-0138-X

[15] A. M. El-Taher and H. A. Madkour, "Distribution and Environmental Impacts of Metals and Natural Radionuclides in Marine Sediments in Front of Different Wadies Mouth along the Egyptian Red Sea Coast," Applied Radiation and Isotopes, Vol. 69, No. 2, 2011, pp. 550-558. doi:10.1016/i.apradiso.2010.11.010
[16] M. Harzhauser, O. Mandic, W. E. Piller, M. Reuter and A. Kroh, "Tracing Back the Origin of the Indo-Pacific Mollusc Fauna: Basal Tridacninae from the Oligocene and Miocene of the Sultanate of Oman," Paleontology, Vol. 51, No. 1, 2008, pp. 199-213. doi:10.1111/j.1475-4983.2007.00742.x

[17] W. A. Newman and E. D. Gomez, "On the Status of Giant Clams, Relics of Tethys (Mollusca: Bivalvia: Tridacninae)," Proceedings of the 9th International Coral Reef Symposium, Bali, 23-27 October 2000, pp. 927-936.

[18] F. Rögl, "Palaeogeographic Considerations for Mediterranean and Paratethys Seaways (Oligocene to Miocene)," Annalen des Naturhistorischen Museums in Wien, Vol. 99A, 1998, pp. 279-310.

[19] M. Harzhauser, W. E. Piller and F. F. Steininger, "Circum-Mediterranean Oligo/Miocene Biogeographic Evolution-The Gastropods Point of View," Palaeogeography, Palaeoclimatology, Palaeoecology, Vol. 183, No. 1-2, 2002, pp. 103-133. doi:10.1016/S0031-0182(01)00464-3

[20] R. K. Wye, "The Encyclopedia of Shells," Oxford University Press, New York, 1991.

[21] A. S. Othman, G. H. S. Goh and P. A. Todd, "The Distribution and Status of Gant Clams (Family Tridacnidae) - A Short Review," The Raffles Bulletin of Zoology, Vol. 58, No. 1, 2010, pp. 103-111.

[22] P. Colin and A. Arneson, "Mollusks: Tropical Pacific Invertebrates," Coral Reef Press, Beverly, 1995.

[23] R. L. Hean and O. J. Cacho, "A Growth Model for Giant Clams Tridacna Crocea and T. Derasa," Ecological Modelling, Vol. 163, No. 1-2, 2002, p. 944.

[24] H. A. Madkour and M. Y. Ali, "Heavy Metals in the Benthic Foraminifera from the Coastal Lagoons, Red Sea, Egypt: Indicators of Anthropogenic Impact on Environment (Case Study)," Environmental Geology, Vol. 58, No. 3, 2009, pp. 543-553. doi:10.1007/s00254-008-1529-0 